\title{
Tết về
}

Khúc Văn Quý

February 12, 2021

Preprint DOI: https://osf.io/mucv2

Ấm áp đủ đầy hương cỗ Tết

Ơn nhớ cội nguồn

Ơn cảm non sông

Chén rượu con say chuyện màu cờ

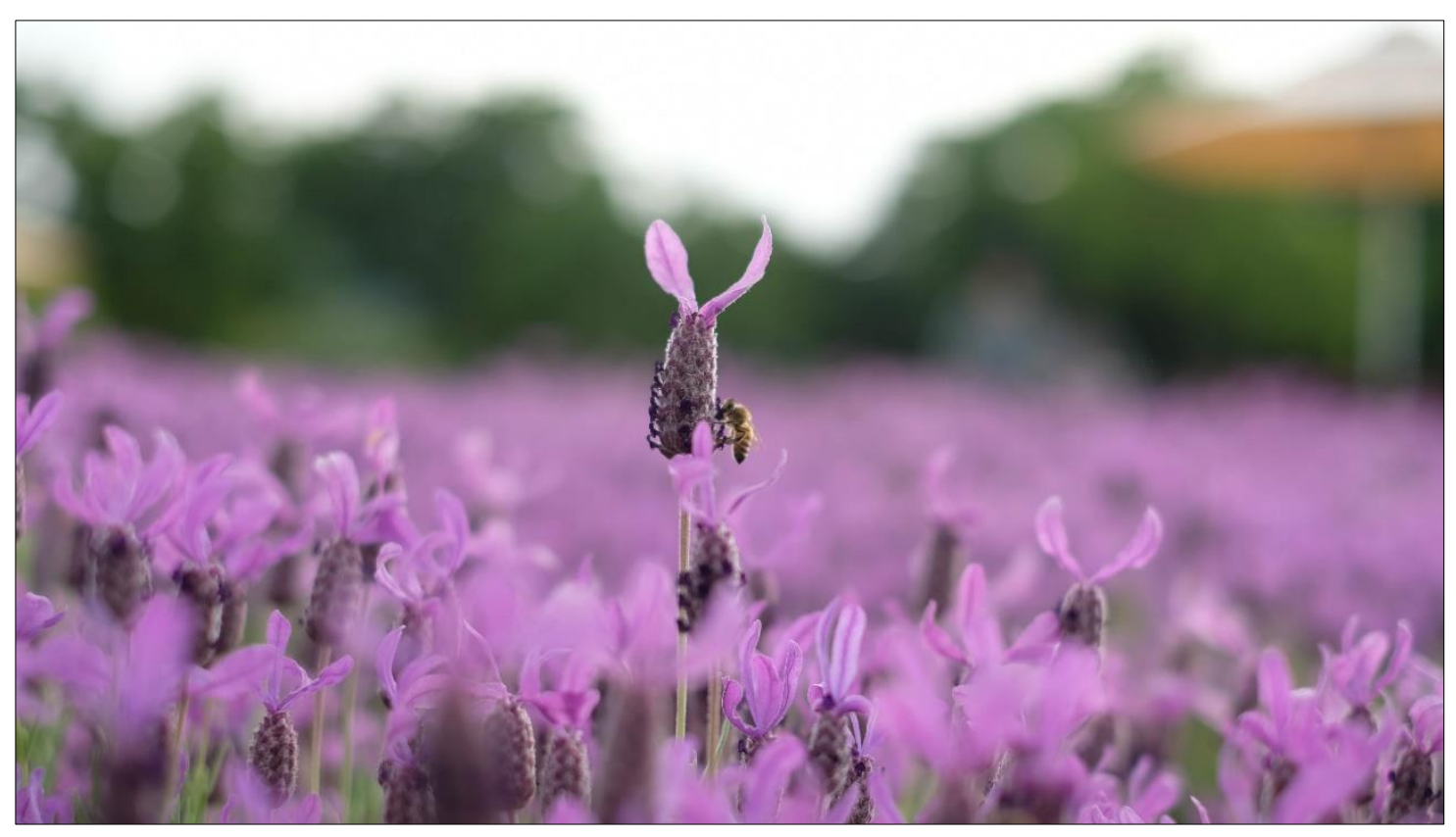

C2020 photo courtesy: Trung Tran 